\title{
Primary Ocular Transmissible Venereal Tumor in a Prepubescent Female Dog
}

\author{
Andréia Vitor Couto do Amaral, Francine Mucha, Igor Borges Oliveira, Camila Franco de Carvalho, \\ Wanessa Ferreira Ataide \& Klaus Casaro Saturnino
}

\begin{abstract}
Background: Canine transmissible venereal tumor (CTVT) is a peculiar neoplasm resulting from the transmission of host cancerous cells to another canid by implantation. Transmission occurs among reproductive age dogs, especially those with unrestricted sexual activity. It usually occurs on the external genitalia of dogs and other areas are unusual. However, implants have been described in injured mucosa, as well as metastases in lymph nodes, spleen, skin, anus and perianal space, oral mucosa, nasal mucosa, eyeball and brain. The purpose of this report is to describe the first case of exclusively extragenital ocular CTVT in a prepubescent female dog.

Case: A 6-month-old mixed-breed, non-spayed and prepubescent female dog, showing a fast-growing reddish-colored mass in the right eye (RE), was examined. Blepharospasm, mild serosanguineous secretion, chemosis and a smooth surface reddish mass with $2.5 \mathrm{~cm}$ in length occupying the orbital area were observed during physical examination, impairing the visualization of the right eyeball. For ocular ultrasonography examination of the affected eye, acepromazine was used $(0.03$ $\mathrm{mg} / \mathrm{kg}$ ) associated with methadone $(0.3 \mathrm{mg} / \mathrm{kg})$ intramuscularly, and propofol $(4 \mathrm{mg} / \mathrm{kg})$ for induction and $0.2 \mathrm{mg} / \mathrm{kg}$ for maintenance, intravenously. Ultrasonography examination evidenced an amorphous hyperechogenic structure, medial to the RE, with homogeneous echotexture, punctiform vascularization to amplitude Doppler (Power Doppler), measuring 2.8 $\mathrm{cm}$ in length and $1.4 \mathrm{~cm}$ in diameter, causing eyeball distortion and rejection. Based on ultrasonography results and with the patient still anesthetized, an incisional biopsy of the peribulbar mass was performed with a $5 \mathrm{~mm}$ disposable punch. The final CTVT diagnosis was possible after histopathological analysis. No more CTVT nodules were found, especially in the vulva, which had a prepubescent appearance, consistent with age. Treatment with 4 sessions of chemotherapy with vincristine sulfate resulted in complete remission of the tumor mass. In the second session, it was already possible to visualize the eyeball with a significant remission of the tumor mass, ruling out neoplastic exceresis. At this time, threat response, normal direct and consensual photopupillary reflexes, normal eyelid reflex, corneal surface without slit lamp biomicroscopy and fluorescein staining were present in the RE. Nevertheless, there were mild diffuse corneal edema and slight ciliary injection. One percent prednisolone eye drops $(8 / 8 \mathrm{~h})$ and tobramycin eye drops $(6 / 6 \mathrm{~h})$ were prescribed for 1 week. In the fourth session of chemotherapy, no changes were observed in the RE.

Discussion: In the present case, the diagnosis of CPVD in a prepubertal patient, primary orbital TVTV, and the fact that the structure of the eye bulb and visual function remain intact, even with the significant volume of orbital neoplasia, are highlighted. A single report of skin CTVT in an 11-month-old prepubescent female dog was found. It is important to emphasize that CTVT is typically of dogs of reproductive age that have genital masses. Usually, extragenital masses are related to the act of licking, scratching, biting or sniffing the primary tumor (self-implantation), or rarely, by metastasis, a fact not observed in the present report, since the ocular mass was the only manifestation. Treatment was conducted according to indications of the literature. Four injections of vincristine sulfate were necessary, observing complete remission of the tumor mass with no relapse after 30 days. In this case report, it was possible to observe that CTVT may reveal unusual behaviors regarding epidemiology, which, added to the rare form of exclusively extragenital ocular clinical manifestation, impose a diagnostic challenge, making the histopathological examination an important tool for diagnosis.
\end{abstract}

Keywords: dog, eye, extragenital, Sticker's Tumor. 


\section{INTRODUCTION}

The canine transmissible venereal tumor (CTVT) is a peculiar neoplasm resulting from the transmission of cancerous cells of the host to another canid by implantation process [34]. Transmission occurs among reproductive age dogs, especially those with unrestricted sexual activity and access to the streets, by cell implantation during coitus, licking or interaction between the infected animal and the susceptible host $[7,29,31]$. It usually occurs on the external genitalia of male and female dogs and cases not affecting the genital area are unusual. However, implantation in extragenital areas, especially on injured mucosa, and metastases were described in spleen [5], skin [1], nasal mucosa [14,22], eyeball [3,5,21], brain [11], lymph nodes, anus and perianal space, oral mucosa, among other sites [16,28].

CTVT can be classified as evidencing a plasmacytoid aspect when at least $70 \%$ of neoplastic cells are ovoid with lower nucleus : cytoplasm ratio and eccentric nucleus, as lymphocytic aspect when at least $70 \%$ of tumor cells resemble lymphocytes (round) with higher nucleus : cytoplasm ratio and round and central nucleus or even as lymphoplasmacytic or mixed aspect $[2,20]$.

The most cited treatment is chemotherapy with vincristine sulfate $[6,17,24,27,32]$. However, depending on the extent and size of tumor, affected area, relapses or therapeutic failure, a combination of chemotherapeutic agents [4,15], surgical excision [24], electrochemotherapy [23] or immunomodulators $[9,26,30]$ can be used.

The purpose of this report is to describe the first case of exclusively extragenital ocular CTVT in a prepubescent female dog.

\section{CASE}

A 6-month-old mixed-breed, non-spayed and prepubescent female dog was examined at the Jataí Regional Campus of the Federal University of Goiás with a history of a fast-growing reddish-colored mass in the right eye (RE). According to the guardian, the mass had initially emerged as a small structure in the nasal corner of the RE palpebral fissure and, over the course of two weeks, it quickly occupied the entire orbital area.

A complete ophthalmic examination was performed in the left eye (LE), including threat response, eyelid reflex, direct photopupillary reflex, tear production rate, tonometry, direct ophthalmoscopy and slit lamp biomicroscopy, with no abnormality observed.
Blepharospasm, mild serosanguineous secretion, chemosis and a smooth surface reddish mass measuring approximately $2.5 \mathrm{~cm}$ in length occupying a large portion of the orbital area were observed during physical examination of the RE, impairing the visualization of the right eyeball. At the center of the mass, there was a grayish coloration area measuring approximately $8 \mathrm{~mm}$ in length.

As patient showed discomfort when the RE was manipulated for ocular ultrasonography examination, acepromazine (Acepran $\left.{ }^{\circledR} 0.2 \%\right)^{1}$ was applied at a dose of $0.03 \mathrm{mg} / \mathrm{kg}$ associated with methadone $\left(\text { Mytedom }^{\circledR}\right)^{2}$ at a dose of $0.3 \mathrm{mg} / \mathrm{kg}$ intramuscularly as well as propofol $\left(\text { Provive }^{\circledR}\right)^{3}$ at a dose of $4 \mathrm{mg} / \mathrm{kg}$ for induction and $0.2 \mathrm{mg} / \mathrm{kg}$ intravenously for maintenance.

Ultrasonography examination evidenced an amorphous hyperechogenic structure, medial to the RE, with homogeneous echotexture, punctiform vascularization to amplitude Doppler (Power Doppler, SonoAce R $\left.3^{\circledR}\right)^{4}$, measuring about $2.8 \mathrm{~cm}$ in length and $1.4 \mathrm{~cm}$ in diameter, causing eyeball distortion and rejection (Figure 1).

In view of the ultrasonography examination results and with the patient still anesthetized, an incisional biopsy of the peribulbar mass was performed with a $5 \mathrm{~mm}$ disposable punch. The sample was stored in a vial containing $10 \%$ buffered formaldehyde solution and submitted for routine histopathological evaluation. A complete blood count and a biochemical profile were also evaluated, indicating only mild eosinophilia.

Tramadol (Dorless $\left.{ }^{\circledast}\right)^{5}$ was prescribed at a dose of $4 \mathrm{mg} / \mathrm{kg}$ every $12 \mathrm{~h}$, orally, for 1 week, and the Elizabethan collar and local cleansing with saline solution and gauze were indicated until the results of the histopathological examination.

Histopathological examination of the mass biopsy revealed hypercellularity, with round to ovoid cells, moderate eosinophilic cytoplasm, predominantly eccentric nuclei and high mitotic level with predominantly plasmacytoid aspect (Figure 2), establishing the CTVT diagnosis according to the literature described $[2,20]$.

In view of the histopathological examination results, which occurred ten days after the initial appointment, the patient was referred for chemotherapy treatment with vincristine sulfate $\left(\text { Tecnocris }^{\circledR}\right)^{6}$ at a dose of $0.03 \mathrm{mg} / \mathrm{kg}$. It was observed that the mass had grown expressively in the ocular orbit, showing reddish coloration, friable aspect, necrosis areas, sanguineous 
secretion and foul odor characteristic of CTVT. The evolution of the tumor mass in 10 days can be observed in Figure 3.

At the time, a new physical examination was performed in the patient to inspect and search for possible CTVT nodules, especially on the vulva, however only evidencing the organ with prepubescent aspect, consistent with the age. Submandibular, pre-scapular and popliteal lymph nodes showed no volume alterations on palpation. Vaginal cytology was performed searching for neoplastic cells on slides stained with fast panoptic. The results of the samples analyzed were negative.

The chemotherapeutic protocol consisted of four vincristine sulfate applications at the dose described, with seven-day interval between applications, by slow venous infusion with $0.9 \% \mathrm{NaCl}$ solution? Before each application, a blood sample for complete blood count and biochemical profile was collected in order to monitor possible complications to the chemotherapy protocol, observing only lymphocytosis.

In the second session of chemotherapy, it was already possible to visualize the eyeball with a fairly significant remission of the tumor mass, discarding a possible surgical procedure for neoplasm excision as part of the treatment. However, a complete RE examination was not yet possible due to the presence of the mass, though the presence of threat response, normal direct and consensual photopupillary reflexes, normal eyelid reflex, corneal surface with no ulceration at slit lamp biomicroscopy and fluorescein staining were observed in the RE, nevertheless with mild diffuse corneal edema and slight ciliary injection. Prednisolone eye drops (Predfort $\left.{ }^{\circledR}\right)^{8}$ every $8 \mathrm{~h}$ and tobramycin eye drops $\left(\text { Tobre }{ }^{\circledR}\right)^{9}$ every $6 \mathrm{~h}$ were prescribed for 1 week.

In the fourth session of chemotherapy, a complete ophthalmic examination of the RE and LE was performed, and no changes were observed. At the time, a sample was collected for conjunctival cytology to search for neoplastic cells on slides stained with fast panoptic. No neoplastic cells were found in the samples. The clinical aspect of tumor mass involution can be observed in Figure 4.

The patient was examined again 30 days after the fourth session of chemotherapy and no signs of tumor growth were observed.

\section{DISCUSSION}

Some noteworthy specificities of this case report are the diagnosis of CTVT in a prepubescent patient, the primary orbital CTVT and the fact that the ocular bulb structure and the visual function remained intact, even with the expressive volume of orbital neoplasm.

A single report of CTVT in an 11-month-old prepubescent female dog manifested on the skin was found [19]. Similarly to the findings of this case report, that study by Marcos et al. [19] was an exclusive extragenital (cutaneous) occurrence, justifying social interaction and not sexual behavior for tumor transmission. However, this case report is the first to describe an exclusively extragenital ocular CTVT in a prepubescent female dog.

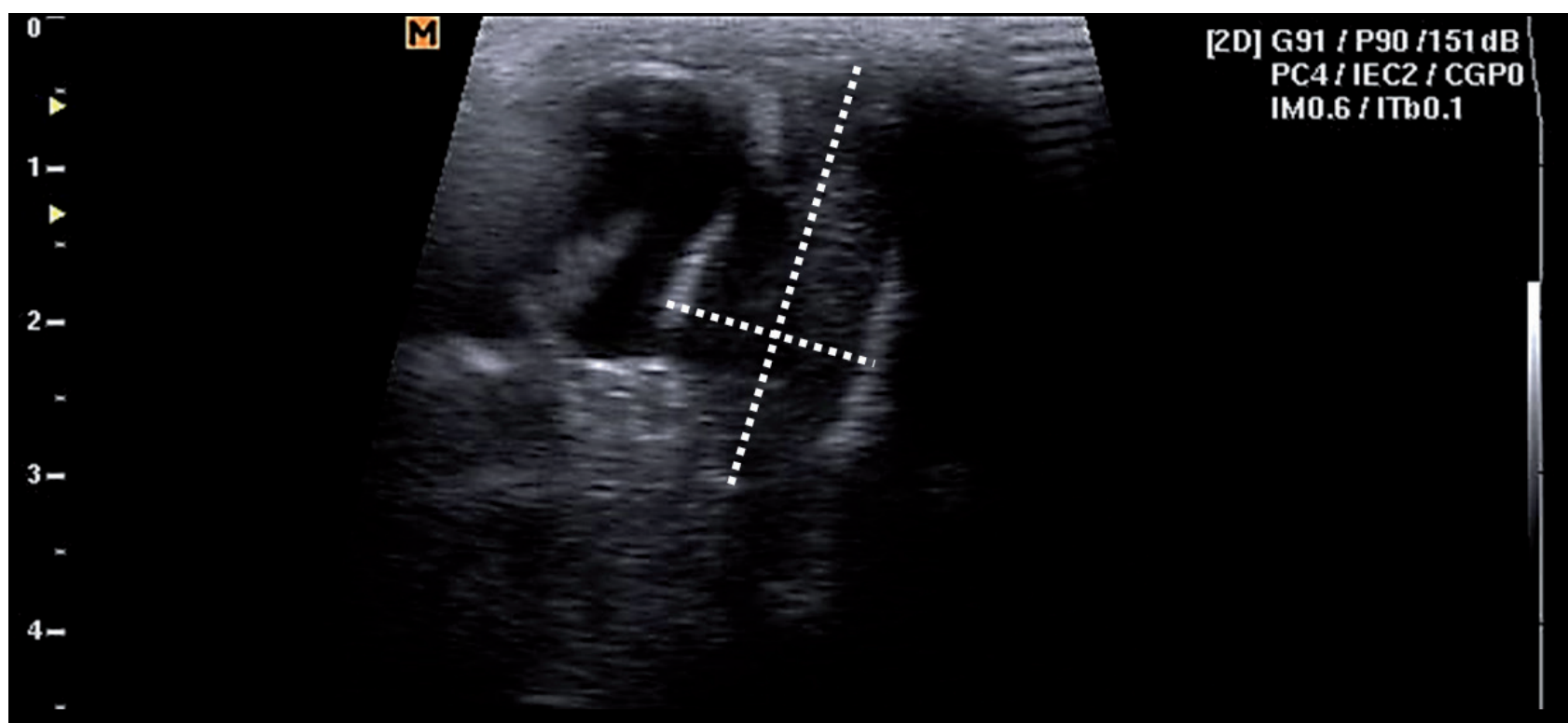

Figure 1. Presence of an amorphous hyperechogenic structure (arrow), medial to the right eye, with homogeneous echotexture, measuring about $2.8 \mathrm{~cm}$ in length and $1.4 \mathrm{~cm}$ in diameter, causing eyeball distortion. 


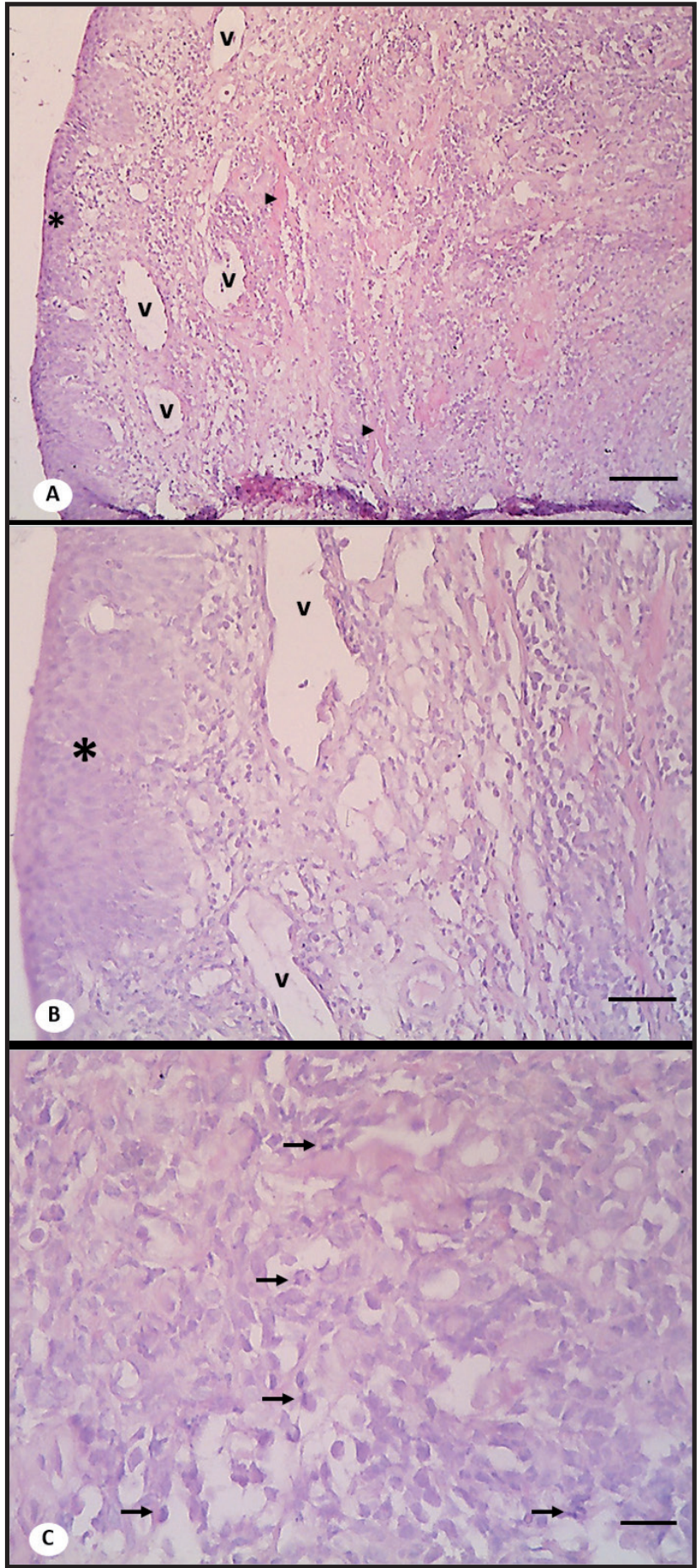

Figure 2. Six-month-old mixed-breed female dog. Macro and microscopic images of orbital mass biopsy. A- Microscopic image showing hypercellularity with well-delimited contour cells infiltrating between delicate dermal collagen fibers (arrowhead) and abundant blood vessels (v) [HE $100 x ;$ Bar $=100 \mu \mathrm{m}]$. B- Same sample in greater detail, showing relatively uniform round to ovoid cells, arranged in the form of lines and "ropes". Vascularization (v) is preserved [HE 200x; Bar= $50 \mu \mathrm{m}$ ]. C- Greater microscopic detailing of sample showing cells with moderate eosinophilic cytoplasm, predominantly eccentric nuclei and high mitotic level (arrows) [HE 400x; Bar $=20 \mu \mathrm{m}]$. (*) epidermis.

It is believed that social interaction occurred with infected street dogs, although the guardian stated that the patient did not have access to the streets and

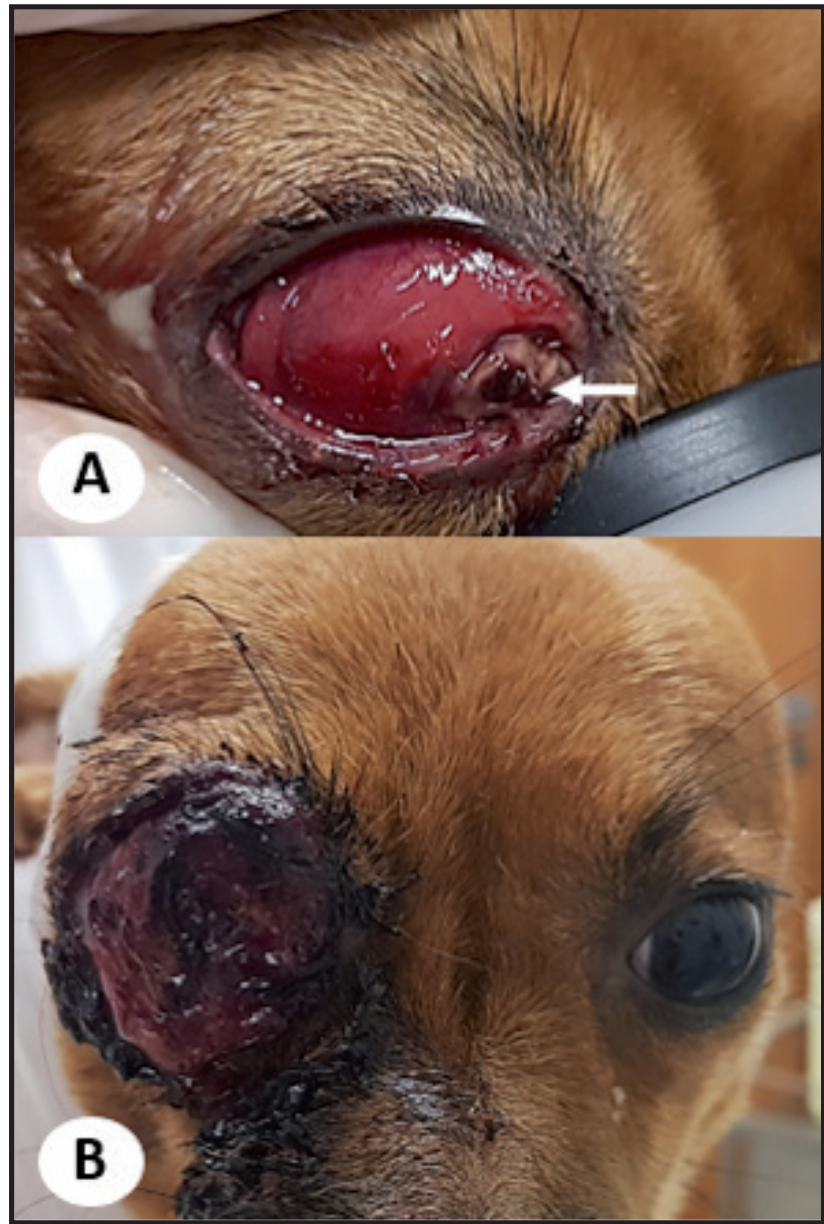

Figure 3. Six-month-old mixed-breed female dog with ocular CTVT diagnosis prior to the start of chemotherapy. A- Reddish coloration mass filling the right orbit, with apparent necrosis area (white arrow), at the time of the first physical examination. B- Mass evolution in 10 days, revealing expressive growth in the ocular orbit, reddish coloration, friable aspect, necrosis areas and sanguineous secretion.

considering that other contacting dogs in the same house did not have the disease. It is suspected that contact with an infected street dog occurred through the residential gate, since the guardian reported the presence of wandering dogs nearby.

It is important to emphasize that CTVT typically affects reproductive age dogs and its main clinical manifestation is the presence of genital masses. Commonly, the presence of extragenital masses is related to the act of licking, scratching, biting or sniffing the primary areas affected by the tumor (self-implantation), or rarely by metastasis $[8,16,18,25]$. However, these were not the hypotheses for the case, since the ocular mass was the only manifestation.

There was exuberant growth of the tumor mass ten days after the first appointment. The diagnosis delay may be justified by the unusual manifestation of CTVT [10,30]. Otherwise, the chemotherapeutic 


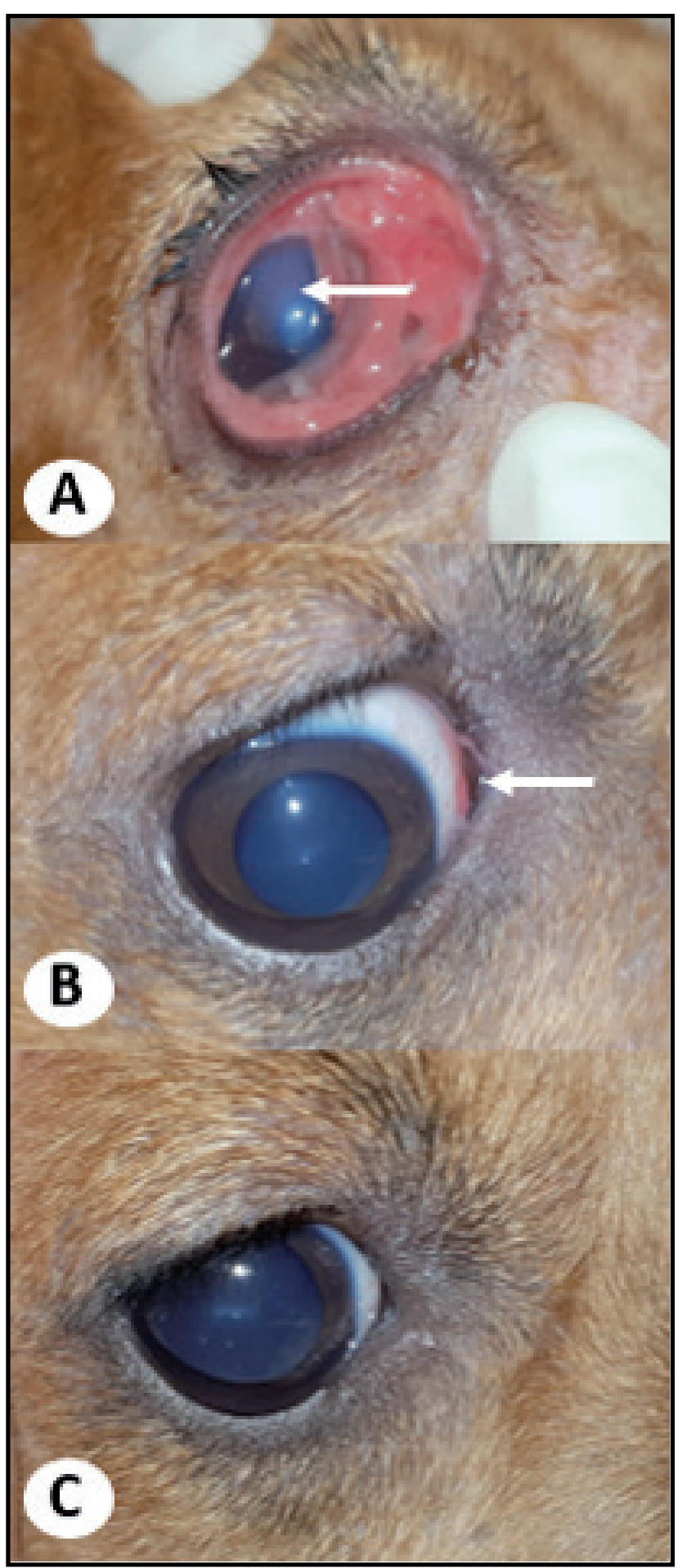

Figure 4. Six-month-old mixed-breed female dog with ocular CTVT diagnosis after the start of chemotherapy. A- Seven days after the first session of chemotherapy with vincristine sulfate. A pinkish coloration tumor mass in scleral and third eyelid conjunctives and mild to moderate diffuse corneal edema (white arrow). B- Seven days after the third session of chemotherapy, a small pinkish coloration mass in the conjunctiva (white arrow). C-Seven days after the fourth session of chemotherapy, with no signs of ocular mass.

protocol could have been started on the same day of the first appointment, avoiding the patient suffering and guardian's anguish.
Treatment was conducted according to indications of the literature [33]. Four injections of vincristine sulfate were necessary, observing complete remission of the tumor mass with no relapse after 30 days. In the study conducted by Paranzini et al. [24], the $6.27 \pm 1.82$ mean of vincristine sulfate applications was found, with a minimum of one and a maximum of eleven sessions of chemotherapy. The authors reported that the need for more than four doses of chemotherapy or combination of protocols was common for the remission of tumor masses of CTVT. However, this was not observed in our case report, which showed excellent response to vincristine, revealing significant remission shortly after the first application.

Resistance to chemotherapy with vincristine sulfate on CTVT could be found, especially in plasmacytoid tumors, where a higher expression of P-glycoprotein was observed [13]. However, in this case, the response to chemotherapy was effective.

Ocular lesions as the only manifestation of CTVT in 22 dogs were reported by Komnenou et al. [17], where most of the subjects were male dogs between 2 and 7 years old. According to the authors, the tumor masses were mainly on the bulbar conjunctiva of the nictitating membrane, similarly to the one observed in this case report, in which it was possible to notice the location of the mass more accurately during the second session of chemotherapy, in which it already showed remission, enabling a better inspection of ocular structures.

The most frequent occurrence of CTVT on the nictitating membrane and on the ocular structure was explained by the fact that this membrane constitutes a protection to the ocular bulb, that protrudes due to some aggression, being susceptible to being compromised and injured during the sexual behavior of the dog sniffing and licking, allowing the inoculation of tumor cells [17]. It is believed that something similar occurred to the patient of our case report, with social rather than sexual behavior.

In the study by Komnenou et al. [17], deep ulcerative keratitis was observed in $32 \%$ of the dogs due to the presence of tumor mass in the palpebral conjunctiva or in the nictitating membrane. In our case report, no corneal ulcer was observed. It is believed that the absence of the corneal lesion occurred due to the short time of exposure of the ocular surface to the tumor mass or the absence of previous eye injury. 
In this case report, it was possible to observe that CTVT may reveal unusual behaviors regarding epidemiology, which, added to the rare form of exclusively extragenital ocular clinical manifestation, impose a diagnostic challenge, making the histopathological examination an important tool for diagnosis.

\section{MANUFACTURERS}

${ }^{1}$ Vetnil-Indústria e Comércio de Produtos Veterinários Ltda. Louveira, SP, Brazil.

${ }^{2}$ Cristália Produtos Químicos Farmacêuticos Ltda. Itapira, SP, Brazil.
${ }^{3}$ União Química - Farmacêutica Nacional S/A. São Paulo, SP, Brazil.

${ }^{4}$ Samsung Medison. Seoul, South Korea.

${ }^{5}$ Agener-União Saúde Animal - Farmacêutica Nacional S/A. São

Paulo, SP, Brazil.

${ }^{6}$ Zodiac Produtos Farmacêuticos S/A. Pindamonhangaba, SP, Brazil.

${ }^{7}$ Equiplex Indústria Farmacêutica. Anápolis, GO, Brazil.

${ }^{8}$ Allergan Brazil. Guarulhos, SP, Brazil.

${ }^{9}$ Novartis Biociências S/A. São Paulo, SP, Brazil.

Declaration of interest. The authors report no conflicts of interest. The authors alone are responsible for the content and writing of this paper.

\section{REFERENCES}

1 Albanese F., Poli A., Millanta F. \& Abramo F. 2002. Primary cutaneous extragenital canine transmissible venereal tumour with Leishmania-laden neoplastic cells: a further suggestion of histiocytic origin? Veterinary Dermatology. 13(5): 243-246.

2 Amaral A.S., Gaspar L.F.J., Silva S.B. \& Rocha N.S. 2004. Diagnóstico citológico do tumor venéreo transmissível na região de Botucatu, Brasil (estudo descritivo: 1994-2003). Revista Portuguesa de Ciências Veterinárias. 99(551): 167-171.

3 Amaral A.V.C., Oliveira R.F., Silva A.P.S.M., Baylão M.L., Luz L.C \& Santana F.J.F. 2012. Tumor venéreo transmissível intra-ocular em cão: relato de caso. Veterinária e Zootecnia. 19: 79-85.

4 Amber E.I., Henderson R.A., Adeyanju J.B. \& Gyang E.O. 1990. Single-Drug Chemotherapy of canine transmissible venereal tumor with cyclophosphamide, methotrexate, or vincristine. Journal of Veterinary Internal Medicine. 4(3): 144-147.

5 Batista J.S., Soares H.S.S., Pereira R.H.M.A., Petri A.A., Sousa D.N.S. \& Nunes F.C.R. 2007. Tumor venéreo transmissível canino com localização intra-ocular e metástase no baço. Acta Veterinaria Brasilica. 1(1): 45-48.

6 Chokeshaiusaha K., Puthier D., Nguyen C., Sudjaidee P. \& Sananmuang T. 2019. Factor Analysis for Bicluster Acquisition (FABIA) revealed vincristine-sensitive transcript pattern of canine transmissible venereal tumors. Heliyon. 5: $1-8$.

7 Dabus D.M.M., Tentrin T.C., Bocardo M., Lima G.S., Lot R.F.E., Bariani M.E. \& Rocha N.S. 2008. Estudo epidemiológico do tumor venéreo transmissível baseado nos padrões plasmocitóide e linfocitóide em cães atendidos no Hospital Veterinário da Faculdade de Medicina Veterinária e Zootecnia de Garça. Revista Científica Eletrônica de Medicina Veterinária. 11(1): 1-7.

8 Dass L.L., Sahay P.N., Kahn A.A.\& Jha G.J. 1986. Malignant transmissible veneral tumor. Canine Practice. 13(3): $15-18$.

9 Den Otter W., Hack M., Jacobs J.J.L., Tan J.F.V., Rozendaal L. \& Van Moorselaar R.J.A. 2015. Effective Treatment of Transmissible Venereal Tumors in Dogs with Vincristine and IL2. Anticancer Research. 35: 3385-3392.

10 Duzanski A.P., Fêo H.B., Montoya L.M., Seullner C.V. \& Rocha N.S. 2017. Canine Transmissible Venereal Tumor: Is Its Biological Behavior Changing? The Anatomical Record. 300(6): 1009-1010.

11 Ferreira A.J.A., Jaggy A., Varejäo A.P., Ferreira M.L., Correia J.M., Mulas J.M., Almeida O., Oliveira P. \& Prada J. 2000. Brain and ocular metastases from a transmissible venereal tumour in a dog. Journal of Small Animal Practice. 41(4): 165-168.

12 Ganguly B., Das U. \& Das A.K. 2013. Canine transmissible venereal tumour: a review. Veterinary and Comparative Oncology. 14(1): 1-12.

13 Gaspar L.F.J., Amaral A.S., Bassani-Silva S. \& Rocha N.S. 2009. Imunorreatividade à glicoproteína-p no tumor venéreo transmissível canino. Veterinária em Foco. 6(2): 140-146.

14 Ginel P.J., Molleda J.M., Novales M., Martín E., Margarito J.M. \& López R. 1995. Primary transmissible venereal tumor in the nasal cavity of a dog. The Veterinary Record. 136(9): 222-223. 
15 Javanbakht J., Pedram B., Taheriyan M.R., Khadivar F., Hosseini S.H., Abdi F.S., Hosseini E., Moloudizargari H., Aghajanshakeri S.H., Javaherypour S., Shafiee R. \& Emrani R. 2014. Canine transmissible venereal tumor and seminoma: a cytohistopathology and chemotherapy study of tumors in the growth phase and during regression after chemotherapy. Tumor Biology. 35(6): 5493-5500.

16 Kabuusu R.M., Stroup D.F. \& Fernandez C. 2010. Risk factors and characteristics of canine transmissible venereal tumors in Grenada, West Indies. Veterinary and Comparative Oncology. 8(1): 50-55.

17 Komnenou A.T., Thomas A.L.N., Kyriazis A.P., Poutahidis T. \& Papazoglou L.G. 2015. Ocular manifestations of canine transmissible venereal tumour: a retrospective study of 25 cases in Greece. The Veterinary Record. 176(20): 1-5.

18 Lin S.C., Chuang T.F., Lin C.S., Lin D.S. \& Liao A.T. 2014. Immune characterization of peripheral blood mononuclear cells of the dogs restored from inoculation of canine transmissible venereal tumor cells. Taiwan Veterinary Journal. 40(4): 181-190.

19 Marcos R., Santos M., Marrinhas C. \& Rocha E. 2006. Cutaneous transmissible venereal tumor without genital involvement in a prepubertal female dog. Veterinary Clinical Pathology. 35(1): 106-109.

20 Meuten D.J. 2002. Tumors in Domestic Animals. 4th edn. Ames: Iowa State Press, 800p.

21 Milo J. \& Snead E. 2014. A case of ocular canine transmissible venereal tumor. The Canadian Veterinary Journal. 55(1): 1245-1249.

22 Ojeda J., Mieres M., Soto F., Arnes V., Paredes E. \& Navarrete M. 2018. Computer tomographic imaging in 4 dogs with primary nasal canine transmissible venereal tumor and differing cellular phenotype. Journal of Veterinary Internal Medicine. 32(3): 1172-1177.

23 Osorio-Morales L.F \& Pedraza-Ordóñez F. 2017. Electrochemotherapy Treatment of Canine Transmissible Venereal Tumors. Artificial Organs. 41(12): 1185-1185.

24 Paranzini C.S., Sant'anna M.C., Santis G.W \& Martins M.I.M. 2015. Prevalence of different cytomorphological types of transmissible venereal tumours and the association with prognosis in dogs treated with vincristine sulphate Retrospective study. Semina: Ciências Agrárias. 36(6): 3795-3800.

25 Pereira J.S., Silva A.B., Martins A.L., Ferreira A.M. \& Brooks D.E. 2000. Immunohistochemical characterization of intraocular metastasis of a canine transmissible venereal tumor. Veterinary Ophthalmology. 3(1): 43-47.

26 Ramos-Zayas Y., Franco-Molina M.A., Hernádez-Granados A.J., Zárate-Triviño D.G., Coronado-Cerda E.E., Mendoza-Gamboa E., Zapata-Benavides P., Ramírez-Romero R., Santana-Krymskaya S.E., Tamez-Guerra R. \& Rodríguez-Padilla C. 2018. Immunotherapy for the treatment of canine transmissible venereal tumor based in dendritic cells pulsed with tumoral exosomes. Immunopharmacology and Immunotoxicology. 41(1): 48-54.

27 Raposo A.C.S., Gomes Junior D.C., Lima F.B., Araujo N.L.L.C. \& Oriá A.P. 2014. Tumor venéreo transmissível primário em conjuntiva palpebral de cão: relato de casos. Enciclopédia Biosfera. 10(19): 1803-1809.

28 Sant'ana F.J.F., Lima T.F., Souza F.R., Rabelo R.E., Romani A.F. \& Kunz T.L. 2004. Caracterização anatomopatológica do Tumor Venéreo Transmissível em cães atendidos na Escola de Veterinária da UFG/CAJ. In: Resumos do XXXI Congresso Brasileiro de Medicina Veterinária (São Luis, Brasil). 1 CD-ROM.

29 Santos F.G.A., Vasconcelos A.C., Moro L., Nunes J.E.S. \& Paixão T.A. 2001. Apoptose no tumor venéreo transmissível canino: características morfológicas e evidenciação bioquímica. Arquivo Brasileiro de Medicina Veterinária e Zootecnia. 53(5): 557-562.

30 Setthawongsin C., Tangkawattana S., Rungsipipat A. \& Techangamsuwan S. 2019. In vitro Effect of Recombinant Feline Interferon- $\Omega(\mathrm{rFeIFN}-\Omega)$ on the Primary CanineTransmissible Venereal Tumor Culture. Frontier in Veterinary Science. 6(104): 1-7.

31 Tinucci-Costa M. 2008. Tumor Venéreo Transmissível Canino. In: Daleck C.R., Nardi A.B. \& Rodaski S. (Eds). Oncologia em Cães e Gatos. São Paulo: Roca, pp.539-556.

32 Varughese E., Singla V., Ratnakaran U. \& Gandotra V.K. 2012. Successful Management of Metastatic Transmissible Venereal Tumour to Skin of Mammary Region. Reproduction in Domestic Animals. 47(6): 366-369.

33 Viana F.A.B. 2019. Guia Terapêutico Veterinário. 4.ed. Lagoa Santa: Editora Cem, 528p.

34 Wang X., Zhou B., Yang M., Yin T., Chen F., Ommeh S., Esmailizadeh A., Turner M., Poyarkov A., Savolainen P., Wang G., Fu Q. \& Zhang Y. 2019. Canine transmissible venereal tumor genome reveals ancient introgression from coyotes to pre-contact dogs in North America. Cell Research. 29: 1-4.

http://seer.ufrgs.br/ActaScientiaeVeterinariae

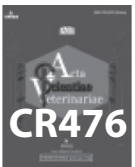

